ANDRZEJ F. DZIUBA, ŁOWICZ

\title{
SZALEŃSTWO CHRZEŚCIJAŃSTWA: TEOLOGIA I ŚWIADECTWO
}

W tradycji, zwłaszcza Kościołów wschodnich, istnieje szczególna kategoria świętych. Byli oni nazywani „szaleńcami Bożymi” m.in. z powodu nadzwyczajności, czasem nawet dziwności ich życia. Tak oceniani, jednocześnie byli szanowani, a nawet uwielbiani. Zatem, czy życie świętego, szalonego miłością do Boga, może stać się pouczającym świadectwem szaleńczej miłości Boga do człowieka? Jednocześnie jest to przecież powszechne powołanie, już zapoczątkowane w chrzcie św. ${ }^{1}$ Wszyscy powinni żyć ,jak przystoi świętym” $($ Ef 5,3) i przyoblec się, ,jako (...) wybrańcy Boży - święci i umiłowani - (...) w serdeczne miłosierdzie, dobroć, pokorę, cichość, cierpliwość" (Kol 3,12).

Człowiek, w swym realnym istnieniu, odczuwa potrzebę Boga bardzo rozsądnego, a zatem bardzo źle znosi, gdy ku Niemu nie idzie się według poprawnych reguł i dobrych zasad (por. Mt, 19,17). „Arlekini” Boga potrzebują cyrków do pewnej samozadowalającej intymności i egoistycznej prezentacji siebie. Ochraniani są często, z troską, przez opiekunów, aby nie ponieść szkód w uznaniu kościelnego szacunku, który często trwa tylko dlatego, że otacza się formułą „tak zawsze czyniono”. To schematyzm obrony przed fantazją wiary, jej bogactwem i twórczą obecnością wśród ludzi i w świecie. Takiej

1 Por. J a n P a w e $\nmid$ II. Adhortacja apostolska „Christifideles laici”, Citta del Vaticano 1988, nr 16-17; t e n ż e, „Nie lękajcie się być świętymi”. Homilia podczas Mszy św. i kanonizacji bt. Kingi. Stary Sacz, 16 VI 1999, L'Osservatore Romano 20(1999)8, nr 4-5. 
drogi, jeśli ma być autentycznym chrześcijańskim szaleństwem, nie da się do końca zaprogramować. ${ }^{2}$

\section{Błędne koła}

Można pytać, do jakiego stopnia dla chrześcijanina ma znaczenie czysty rozsądek i na ile jest on wiążący w postępowaniu moralnym. Nie jest to pytanie bez znaczenia, jeśli ma się na względzie fakt, że zło jest zawsze nierozsądne. Co więcej, pytanie to jest niezwykle jasne i może wywierać destabilizujący wpływ.

Właściwie zło, co jest typową dla niego cechą, nie może rodzić nic innego, jak tylko siebie, a więc zło (por. Ps 34,22; 37,12). Czy zatem jest możliwa interwencja wobec tego błędnego kręgu i to tylko za pomocą rozsądku? Teologia, w imię zobowiązania do refleksji nad wiarą, zajmowała się tylko marginesem tego zagadnienia, oryginalnego i wręcz niewiernego, ale nigdy nie zdecydowała się na jego doświadczenie pełne i do końca pogłębione. Wszystko to było często rozeznane jako „bagaż” typowy dla mistyków i tych, którzy w szaleństwie wydeptują drogi Golgoty Pana.

To doświadczenie jest w swej istocie łaską, jest tym, co człowieka przemienia i udoskonala, a przede wszystkim tym, co jednoczy go z Jezusem, który „był przebity za nasze grzechy” (Iz 53,5). ${ }^{3}$ Chrześcijanie od samego początku odznaczali się szczególnym umiłowaniem cierpień - Golgoty - znoszonych z miłości do Boga, gdyż byli głęboko przeświadczeni, że przeżywanie takich doświadczeń upodabnia ich do Chrystusa zbawiającego świat (por. Ga 6,14). ${ }^{4}$ Chodzi

2 Por. te n ż e, List apostolski „Novo millennio ineunte”, Citta del Vaticano 2001, nr 31.

3 Por. te n ż e, Pojednanie - temat centralny przejścia do trzeciego milenium. Zakończenie diecezjalnego Kongresu Eucharystycznego, Teramo, 30 VI 1985, L'Osservatore Romano 6(1985)6-7, s. 24.

4 Por. tenże, List apostolski ,, Salvifici doloris”, Citta del Vaticano 1984, nr 20. 
o ukrzyżowanie dla świata ciała i grzechu (por. Ga 2,19; 1Kor 1,20; 2 Kor 4,4; Ef 2,2). ${ }^{5}$

Krzyż Zbawiciela jest miejscem wielu śmierci: umarł na nim Chrystus za nasze grzechy (por. Rz 6,10), razem z Chrystusem został ukrzyżowany Paweł, by umrzeć dla Prawa (por. Ga 2,19), na krzyżu umarli ci wszyscy, którzy stanowią jedność z Chrystusem i dzięki temu uległo śmierci ciało ze wszystkimi namiętnościami i pożądliwościami (por Ga 5,24); na krzyżu wreszcie znalazł śmierć nasz „stary człowiek" (por. Rz 6,6). ${ }^{6}$

Prawda o Bożym miłosierdziu i o „grzechu zbawionym” nie może prowadzić jednak do lekceważenia grzechu. Konieczna jest postawa nawrócenia do Boga, a tym samym odwrócenie się od grzechu. Pierwszym warunkiem jest uznanie nie tylko prawdy o grzechu, ale także prawdy o tym, że jest się grzesznikiem (por. Ps 51,1-19; Łk 15,11-32). „Uznanie swego grzechu, co więcej - po głębszym spojrzeniu na własną osobowość - uznanie siebie grzesznikiem, zdolnym do popełnienia grzechu i skłonnym do grzechu, jest konieczną zasadą powrotu do Boga"?

Dlatego też jedną z najbardziej dramatycznych przeszkód na drodze nawrócenia jest współczesne zjawisko „utraty poczucia grzechu”. ${ }^{8}$ Wyrasta ono z sekularyzmu, ale też składa się na nie wiele bardziej konkretnych przyczyn. Chodzi tutaj z jednej strony o pewne prądy kulturowe i filozoficzne, które zniekształcają prawdę o człowieku

5 Por. R. Tre m b la y, „Ma io vi dico...”. L'agire eccellente, specifico della morale Cristiana, Bologna 2005, s. 97-102; G. v o n R a d, Teologia Starego Testamentu, Warszawa 1986, s. 560-563; S. L e g a s s e, L'Epitre de Paul aux Galates, Paris 2000, s. 296-306; R. T r e m b l a y, L',,innalzamento” del Figlio, fulcro della vita morale, Roma 2001, s. 51-55.

6 Por. H. S c h 1 i e r, La Lettera ai Romani, Brescia 1982, s. 301-331; F. M u s s n e r, La Lettera ai Galati, Brescia 1987, s. 579-283.

7 J a n P a w 1 II, Adhortacja apostolska „Reconciliatio et paenitentia”, Citta del Vaticano 1984, nr 13.

8 Por. t e n ż e, Encyklika „Dominum et Vivificantem”, Citta del Vaticano 1986, $\mathrm{nr} 47$; t e n ż e, Adhortacja apostolska ,Reconciliatio et paenitentia”, nr 18; t e n ż e, Adhortacja apostolska „Ecclesia in Europa”, Citta del Vaticano 2003, nr 76. 
i prowadzą do relatywistycznej wizji moralności, a z drugiej strony - o zjawisko zaćmienia i znieprawienia ludzkich sumień, do czego mogą się przyczyniać także pewne niewłaściwe praktyki duszpasterskie w Kościele. ${ }^{9}$

\section{Szaleństwo krzyża}

Stwierdzenie, że teologia zapomniała o krzyżu i jego prawdzie, byłoby zatem głęboko niesprawiedliwe. On jest nadal znakomicie i twórczo obecnym w dziejach tej dyscypliny. Niestety, wydaje się jednak, że jednocześnie jest ona coraz bardziej znaczona rozsądkiem. Jest bowiem prawdą, że z szaleństwa krzyża nie zawsze czyniono podstawowy proces interpretacyjny teologii.

Jeśli zatem Chrystus dokonał dzieła odkupienia przez krzyż, jeśli cierpiał za człowieka i dla człowieka, to każdy człowiek jest wezwany do uczestnictwa w tym cierpieniu, przez które także każde ludzkie cierpienie zostało odkupione. ${ }^{10}$ Dokonując odkupienia przez cierpienie, Chrystus wyniósł zarazem ludzkie cierpienie na poziom odkupienia. ${ }^{11} \mathrm{~W}$ ten sposób człowiek, przez swoje cierpienie, może stać się uczestnikiem odkupieńczego cierpienia Chrystusa. ${ }^{12}$ Człowiek jest wezwany do tego uczestnictwa, a wręcz można mówić o swoistym powołaniu do uczestnictwa w cierpieniach Chrystusa (por. 1P 4,13; 5,1; Rz 8,17). Cierpienie w życiu chrześcijanina jest udziałem w cierpieniu Chrystusa i zapewnia udział w chwale Jego paruzji (por. 2Kor 1,5.7; 4,10; Rz 8,17; Flp 3,10). ${ }^{13}$

9 Por. t e n ż e, Adhortacja apostolska „Reconciliatio et paenitentia”, $\mathrm{nr} 18$.

10 Por. t e n ż e, „Cierpienie odkupione”. Homilia podczas Mszy św. dla chorych, Banneux, 21 V 1985, L'Osservatore Romano 6/1985, numer nadzwyczajny/II, nr 4.

11 Por. te n ż e, „Bóg zapłać...” Spotkanie z inwalidami pracy i chorymi. $\mathrm{Ka}$ towice - katedra, 20 VI 1983, L'Osservatore Romano 4/1984, nr nadzwyczajny/II, s. 5.

12 Por. t e n ż e, List apostolski „Salvifici doloris”, nr 19.

13 Por. S. L y o n e t, Liberte chretienne et loi de l'Esprit selon S. Paul, Romae 1954, s. 189-193; R. S c h n a c k e n b u r g, L'esistenza cristiana secondo il Nuovo Testamento, Modena 1971, s. 82-87; A. H i e b e r e t, The Foundations of Paul's Ethics, 
Podobnie jak istnieje makabryczna światłość zła, winna istnieć jeszcze silniejsza jasność szaleństwa krzyża. Chrześcijanin nie znajduje upodobania w cierpieniu, przyjmuje je wówczas, gdy nie daje się ono wyeliminować w imię wyższego dobra (por. Rz 12,21). Tylko taka postawa akceptacji cierpienia pozwala godnie wytrwać w nim, zachowując wiarę w jego sens. ${ }^{14}$

Nauka o grzechu nie jest jedynie hamartiologią, albowiem łączy się ściśle z orędziem o zbawieniu. Kościół uczy o grzechu w perspektywie zbawczego działania Boga, „w którym grzech zostaje skonfrontowany z prawdą Bożej miłości: sprawiedliwej, wielkodusznej i wiernej, ujawniającej się nade wszystko w przebaczeniu i odkupieniu". ${ }^{15} \mathrm{Z}$ jednej strony grzech odsłania tajemnicę nieprawości - misterium iniquitatis, z drugiej - trzeba go widzieć w świetle tajemnicy zbawienia - misterium pietatis, która odsłania zwycięstwo nad grzechem (por. Tt 2,14; Rz 4,7). ${ }^{16}$

Boża miłość „nie zatrzymuje się przed naszym grzechem, nie cofa się przed naszymi przewinieniami, ale staje się jeszcze bardziej troskliwa i wielkoduszna"177 (por. Ps 126,2-3; Rz 2,4). Jest to wyraźne odwołanie się do tajemnicy Bożego miłosierdzia, która w dziejach ludzkich objawia się w Jezusie Chrystusie (por. 1Tm 1,15-16). ${ }^{18}$ Prawda o tym, że miłość i łaskawość Boża jest potężniejsza niż grzech, najpełniej objawia się w krzyżu Chrystusa i potwierdza w Jego zmartwychwstaniu (por. Ps 117,2; Pnp 8,6). ${ }^{19}$ Dlatego też, ,żaden grzech

w: J. G a ffney (red.), Essays in Morality and Ethics, The Annual Publication of the College Theology Society, New York 1980, s. 50-62; H. L a n g k a m m e r, Etyka Nowego Testamentu, Wrocław 1985, s. 199-205; H.-D. W e n d l a n d, Etica del Nuovo Testamento, Brescia 1975, s. 165-169.

14 Por. J a n P aw e ł II, „Krzyż-znakiem nadziei człowieka”. Homilia podczas Mszy św, Brazylia, 30 VI 1980, w: F. K n i o t e k (red.), Nauczanie papieskie, t. III, 1, Poznań-Warszawa 1985, s. 862-865.

15 J a n P aw e 1 II, Adhortacja apostolska ,Reconciliatio et paenitentia”, nr 13.

16 Por. tamże, nr 19.

17 Tamże, nr 22.

18 Por. t e n ż e, Encyklika „Redemptor hominis”, Citta del Vaticano 1979, nr 9.

19 Por. tenże, Encyklika „Dives in miserirordia”, Citta del Vaticano 1980, nr 8. 
człowieka nie może uchylić Bożego Miłosierdzia, nie może go powstrzymać przed ujawnieniem całej swej zwycięskiej mocy, jeśli tylko jej wezwiemy". ${ }^{20}$

Właśnie jasność szaleństwa krzyża - w całej swej głupocie - powinna stać się kategorią teologiczną, która prowadzi do poprawnej interpretacji życia. Z tego stylu interpretacyjnego życia Kościół powinien czerpać ożywczy napój i pożywianie. To winno prowadzić do zaspokojenia pragnienia i głodu autentyzmu świadectwa wiary i życia (por. J 19,35; Dz 1,8; Rz 4,16). ${ }^{21}$ Chodzi o świętość, która jest „podstawowym dziedzictwem synów Bożych” (por. 1P 1,3-4; Ef 1,8), „szczególnym podobieństwem do Chrystusa” (por. Rz 6,5; $1 \mathrm{~J} 3,2$ ), „odzwierciedleniem doskonałości Ojca” (por. Mt 5,48; Hbr 1,1-3). ${ }^{22}$ Tych wielkich dzieł dokonuje Chrystus mocą Ducha Świętego. Człowiek nie może tego osiągnąć bez pomocy łaski. ${ }^{23}$ Świętość także nie może być osiągnięta bez wysiłku człowieka i bez zaangażowania jego wolności. ${ }^{24}$

\section{Ubóstwo teorii}

Co zatem może uratować pełne tragedii miejsca współczesnego świata i dramaty wielu ludzi oraz ludzkich wspólnot (por. 1J 3,15)? Świat pogrążony w nienawiści nie zna życia Bożego. Tylko miłość jest znakiem wspólnoty z Bogiem. „Dążenie do doraźnych interesów prywatnych lub zbiorowych nie może usprawiedliwiać przedsięwzięć, które podsycają przemoc i konflikty między narodami oraz naruszają

20 Te nże, Encyklika „Veritatis splendor”, Citta del Vaticano 1993, nr 118.

${ }_{21}$ Por. V. B a t t a g 1 i a, Gesu crocifisso Figlio di Dio, Roma 1991, s. 11-20; J. K r a m e r, Die Voraussagen des Pfingstgeschehens in Apg 1,4-5 und 8. Ein Beitrag zur Deutung des Pfingstberichtes, w: G. B o r n k a m m, K. R a h n e r (red.), Die Zeit Jesu. Festschrift fur H. Schlier, Freiburg 1970, s. 145-168.

22 Por. J a n P a w e ł II, „Otrzymaliście ducha przybrania za synów”. Orędzie na Światowe Dni Młodzieży 1991, Citta del Vaticano 1991, nr 4.

${ }^{23}$ Por. t e n ż e, List apostolski „,Mulieris dignitatem”, Citta del Vaticano 1988, nr 27.

${ }^{24}$ Por. te n że, Encyklika ,Veritatis splendor”, nr 107. 
międzynarodowy porządek prawny". ${ }^{25}$ Co przerwie liczne spirale przemocy, które ciągle zdają się wzrastać w świecie? Czy wystarczy tu świetlana racjonalność i rozsądek? To jest pytanie o pierwszy trudny do pominięcia krok. Smutkiem i zmartwieniem napawa fakt, gdy pozostanie on tylko pierwszym krokiem. Wystarczy doświadczyć tego wszystkiego z bliska, nawet obok siebie, w swoim sąsiedztwie (por. Ps 15,3; 31,12; Syr 25,1).

Ta solidarność łączy się z wolnością osobową i prawem do przestrzeni ku osobowemu rozwojowi (por. Iz 49,20; 54,2). „Człowiek nie jest sam, żyje z drugimi, przez drugich, dla drugich. Cała egzystencja ludzka ma właściwy sobie wymiar wspólnotowy - i wymiar społeczny. Ten wymiar nie może oznaczać redukcji osoby ludzkiej, jej talentów, jej możliwości, jej zadań. Właśnie z punktu widzenia wspólnoty społecznej musi być dość przestrzeni dla każdego. (...) Ten osobowy rozwój, ta przestrzeń osoby w życiu społecznym jest równocześnie warunkiem dobra wspólnego". ${ }^{26}$

Południe świata jest pod presją ciągłej inwazji, a może i zniewolenia, niesioną pomocą. To interwencje międzynarodowe czy lokalne niosące często lawiny niezliczonych dóbr i środków. To plany rozwoju, proponowane przez analizy różnych ekspertów i przez traktaty polityczne. Jednak ostatecznie funkcjonują w tym mechanizmy wyzysku biednych i słabych przez bogatych i silnych. Narasta i umacnia się rozwarstwienie ekonomiczne i kulturowe ludzkości podział na bogatą Północ i biedne Południe. ${ }^{27}$ Tymczasem autentyczny rozwój człowieka i społeczeństwa to taki, ,który zachowuje

25 KKK 2316.

26 J a n P a w 1 II, ,Nie może być program walki ponad programem solidarności”. Homilia podczas Mszy św. dla świata pracy, Gdańsk-Zaspa, 12 VI 1987, L'Osservatore Romano 8(1987)5bis, nr 7.

27 Por. te n że, Encyklika ,Sollicitudo rei socialis”, Citta del Vaticano 1987, nr 14, 43; t e n ż e, List apostolski, ,Tertio millennio adveniente”, Citta del Vaticano 1994, nr 38; t e n ż e, „Pokój wartością, która nie zna podziałów”. Orędzie na Światowy Dzień Pokoju 1986, Citta del Vaticano 1985. 
szacunek dla osoby ludzkiej we wszystkich jej wymiarach oraz służy jej rozwojowi". ${ }^{28}$

Mimo tego wszystkiego, przepaść między różnymi regionami pogłębia się. Bogactwo teorii okazuje się ostatecznie mało skuteczne, staje się wręcz ubóstwem w realiach życia osobowego i społecznego, w darze szaleńczej miłości. „Prawdziwy rozwój nie może polegać na zwykłym gromadzeniu bogactw i możności korzystania w większym stopniu z dóbr i usług (...) bez należytego uwzględnienia wymiarów społecznych, kulturowych i duchowych istoty ludzkiej”. ${ }^{29}$

\section{Głupota Ewangelii}

Wobec głupoty przemocy, zwłaszcza gdy ukazują się niezwykle silne pęknięcia przeszłości, która zabijała i zabija (por. Rdz 4,2-15; 9,5-6), ${ }^{30}$ jawi się jednocześnie - jako konieczność - głupota Ewangelii. „Dzięki sercu człowiek jest wrażliwy na absolutne wartości dobra, na sprawiedliwość, braterstwo, pokój. Nieład serca jest w sposób szczególny nieładem sumienia (...). Ale sumienie to bywa często zniekształcone, by nie powiedzieć: podporządkowane, przez różne systemy społeczno-polityczne i ideologiczne". ${ }^{31}$ To pytania o nieczułość sumienia (por. Ef 4,19), a z drugiej strony zabieganie, „aby mieć zawsze czyste sumienie wobec Boga i wobec ludzi” (Dz 24,16). ${ }^{32}$

28 Te n że, Encyklika ,Sollicitudo rei socialis”, nr 1.

29 Tamże, $\mathrm{nr} 9$.

30 „Dlatego mocą Chrystusowej władzy udzielonej Piotrowi i jego Następcom, w komunii z biskupami Kościoła Katolickiego, potwierdzam, że bezpośrednie i umyślne zabójstwo niewinnej istoty ludzkiej jest zawsze aktem głęboko niemoralnym”; t e n ż e, Encyklika „Evangelium vitae”, Citta del Vaticano 1995, nr 57.

31 Te n ż e, „Pokój rodzi się z serca nowego”. Orędzie na Światowy Dzień Pokoju 1984, Citta del Vaticano 1983, nr 2.

32 Por. M. R h o n h e i m e r, La prospettiva della morale. Fondamenti dell'etica filosofica, Roma 1994, s. 44-50; H. U. v o n B a 1 t h a s a r, Spiritus Creator. Saggi teologici, t. 3, Brescia 1972, s. 142-147; F. M o n t a g n i n i, Messaggio del regno e appello morale nel Nuovo Tesatmento, Brescia 1976, s. 39-43; H.-D. W e n d l a n d, Etica del Nuovo Testamento, s. 147-156; H. L a n g k m m e r, Etyka Nowego Testamentu, s. 197-201. 
Chodzi o przebaczenie, pojednanie $\mathrm{z}$ wrogami, nie w imię ich racji, ale tylko w imię Boga, który, poniósłszy klęskę, pokonany na krzyżu, pokonał jednocześnie świat i zło. Głupota krzyża niesiona przez Jezusa z Nazaretu okazała się najdoskonalszą drogą ku życiu, także dla innych. Pojednanie jest darem Boga i Jego inicjatywą (por. J 1,10; Rz 5,10; Kol 1,20-22). Ta inicjatywa dopełnia się w tajemnicy Chrystusa Odkupiciela, Sprawcy przebaczenia, który wyzwala człowieka z każdego grzechu. Chrystus przekazał tę władzę jednania Kościołowi (por. 2Kor 5,18). ${ }^{33}$ Chodzi o dzieło odkupienia, które stało się pojednaniem ludzkości z Bogiem (por. Ef 2,16; Kol 1,20.22). Dalej trwa posługa jednania (por. 2Kor 5,18).

Człowiek uświadamia sobie, że bardzo trudne może być deklarowanie przebaczenia przez tego, kto nie ma udziału i nie jest zaangażowany w dramat zabijania, przemocy czy terroru (por. Rz 1,29-32). Gdy bowiem człowiek znieważa Boga i degraduje Jego boskość, wtedy również znieważa siebie i degeneruje swoje człowieczeństwo. $\mathrm{W}$ tym kontekście należy jednak stwierdzić z naciskiem, że w wielu biednych krajach obecne są nasiona i znaki nadziei. Pierwsze z nich zostały rzucone, inne już kiełkują i ukazują się. A więc, są one nadzieją, jeśli nie zostaną przygłuszone czy stłumione, albo i wręcz zniszczone (por. Mt 13,1-9). Zatem, ,jest rzeczą bardzo ważną, ażeby przekroczyć próg nadziei, nie zatrzymywać się przed nim, ale pozwolić się prowadzić”. ${ }^{34}$ Trzeba ,spojrzeć w twarz temu naszemu światu, spojrzeć na jego wartości i problemy, niepokoje i nadzieje, osiągnięcia i porażki". ${ }^{35}$

Nadzieja ma ufność w Bogu, ale jednocześnie obejmuje troskę o dobro wspólne, sprawiedliwość, pokój, solidarność, prawdę i miłość (por. Ps 72,1-2.7-8; Jk 3,16-18; 1 Kor 13,1-13). Zatem, „,oczekiwanie nowej ziemi nie powinno jednak osłabić, lecz raczej rozbudzić gorliwość w doskonaleniu tej ziemi, na której wzrasta ciało naszej rodziny ludzkiej, mogąc

33 Por. J a n P a w e $\nmid$ II, Adhortacja apostolska „Reconciliatio et paenitentia”, nr 8,13 .

${ }_{34}$ Te n ż e, Przekroczyć próg nadziei, Lublin 1995, s. 163.

35 Te n ż e, Adhortacja apostolska ,Christifideles laici”, nr 3. 
już dać pewne wyobrażenie o nowym świecie. Jakkolwiek postęp ziemski należy starannie odróżnić od wzrostu królestwa Chrystusa, o ile jednak może się przyczynić do lepszego urządzenia społeczeństwa ludzkiego, ma on wielkie znaczenie dla królestwa Bożego". ${ }^{36}$

\section{Nadzieje Ewangelii}

Wszystko to są znaki kompletnej głupoty, zwłaszcza tych ludzi, którzy w najciemniejszych i mrocznych kolejach dziejów byli otwarci na nadzieję jawiącą się jako coś niezrozumiałego. Jakie bowiem mogą pojawić się racje nadziei wobec totalnego tryumfu zła (por. Hi 1,2022)? Jednak głupota miłości zdolna jest pokonać zło szaleństwem tych, którzy ją niosą wbrew wszelkiej nadziei. „Nie lękajcie się! Chrystus wie, «co jest w człowieku». Tylko On to wie". ${ }^{37}$ Jednak to „wezwanie «Nie lękajcie się!» musimy odczytywać w bardzo szerokim wymiarze. W pewnym sensie było to wezwanie pod adresem wszystkich ludzi, wezwanie do przezwyciężenia lęku w globalnej sytuacji współczesnego świata. (...) Nie lękajcie się wreszcie siebie samych!"38

Taka nadzieja musi być jednak autentycznie zakotwiczona w Ewangelii, w jej głupocie (por. 1Kor 9,23; Ga 1,6-16). ${ }^{39}$ „Poprzez inkulturację Kościół wciela Ewangelię w różne kultury i jednocześnie wprowadza narody z ich kulturami do swej własnej wspólnoty". ${ }^{40}$ Chodzi tutaj także o „,nowożytne areopagi”, ${ }^{41}$ których ,,jest dziś wiele i są bardzo różne. Są to wielkie tereny współczesnej cywilizacji

\footnotetext{
36 KDK 39.

37 J a n P a w e $\nmid$ II, „Otwórzcie na oścież drzwi Chrystusowi”. Na rozpoczęcie pontyfikatu, 22 X 1978, w: F. K n i o te k (red.), Nauczanie papieskie, t. 1, nr 5.

38 Te n że, Przekroczyć próg nadziei, s. 160.

39 Por. R. Tre m bla y, Voi, luce del mondo... La vita morale dei Cristiani: Dio fra gli uomini, Bologna 2002, s. 109-115; M.-E. B o i s m a r d, La Loi et l'Esprit, Lumiere et vie 21/1955, s. 65-82; O. M e r k, Handeln aus Glauben. Die Motivierungen der paulinischen Ethik, Marburg 1968, s. 54-57; V. P. F u r n i s h, Theology and Ethics in Paul, Nashville-New York 1968, s. 115-132.

40 J a n P a w eł II, Encyklika „,Redemptoris missio”, Citta del Vaticano 1990, nr 52.

${ }^{41}$ Por. tamże, nr 37
} 
i kultury, polityki i ekonomii. Im bardziej Zachód odgrywa się od swych chrześcijańskich korzeni, tym bardziej staje się terenem misyjnym, w znaczeniu wielorakich «areopagów»". ${ }^{42}$

Tylko taka nadzieja zakotwiczona w Ewangelii jest zdolna do szaleńczego Izajaszowego spojrzenia, spojrzenia proroka, który nawet wobec rozkładu politycznego Izraela był zdolny do dostrzeżenia nadziei rajskiego pokoju pomyślności (por. Iz 14,1-3; 66,5-16). Takie osoby nie są wizjonerami, lecz jedynymi, którzy widzą dobrze, którzy są zdolni widzieć głębiej i dalej. „,Dobry człowiek z dobrego skarbca swego serca wydobywa dobro, a zły człowiek ze złego skarbca wydobywa zło. Bo z obfitości serca mówią jego usta" (Łk 6,45).

Trzeba pamiętać, że „podstawą i celem porządku społecznego jest osoba ludzka (...) jest ona czymś, co wyrasta ponad uwarunkowania społeczne, kulturalne i historyczne, bowiem właśnie człowiek, istota obdarzona duszą, dąży do celu, który pozostaje transcendentny wobec zmiennych warunków jego egzystencji”. ${ }^{43}$ „Dzisiaj trzeba na nowo z przekonaniem zalecać wszystkim dążenie do tej «wysokiej miary» zwyczajnego życia chrześcijańskiego". ${ }^{44}$ Chodzi o to, aby „przyoblec człowieka nowego, stworzonego według Boga, w sprawiedliwości i prawdziwej świętości" (Ef 4,24). Każdy człowiek winien przyoblec „,nowego człowieka” (Ef 2,15), aby w Nim zostać na nowo stworzonym (por. Ga 3,27; Rz 13,14). Należy odnowić ducha i myśli (por. 2Kor 4,16; Kol 3,10) ku stworzeniu przez Boga w chrzcie i dzięki wyposażeniu w świętość zgodną z Ewangelią. ${ }^{45}$

bp Andrzej F. DZIUBA

42 Te n ż e, List apostolski „Tertio millennio adveniente”, nr 57.

43 Te n ż e, „Wolność religijna warunkiem pokojowego wspótżycia”. Orędzie na Światowy Dzień Pokoju 1988, Citta del Vaticano 1987, nr 1.

44 Te n ż e, List apostolski „Novo millennio ineunte”, nr 31.

45 Por. E. L a r s s o n, Christus als Vorbild. Eine Untersuchung zu den paulinischen Tauf- und Eikontexten, Uppsala 1962, s. 111-323; A. N o s s o 1, Teologia człowieka w rozwoju. Zarys antropologii teologicznej-na margniesie „Gaudium et spes”, Ateneum Kapłańskie 62/1970, s. 165-174; W. H r y n i e w i c z, Człowiek - istota otwarta na uczestnictwo w Bogu, w: T. B i e l s k i (red.), Powołanie człowieka, t. 3: Być człowiekiem, Poznań-Warszawa 1974, s. 235-248. 
Słowa kluczowe: teologia, świadectwo wiary i życia, krzyż Jezusa Chrystusa, „szaleńcy Boży”

Keywords: theology, witness of faith and life, the Cross of Jesus Christ, "God's fools"

\section{Foolishness of Christianity: Theology and Witness Summary}

In the theology of Eastern Christianity there is a special category of "God's fools." This is a particular image of faith and belongs to those who have had some mystical experience. The cross is marked by reason. This foolishness of the cross is the basic process in theological interpretation. The cross should shine out even more with its foolishness against the glare of evil, as it draws one to the authentic witness of faith and life. Rationality and reason are not sufficient to face evil. The large amount of help and voluminous theories on poverty do not solve the problems of the poor. The "foolishness" of the Gospel stands up against the foolishness of violence. Victory means forgiveness in God's name, who appeared to lose the battle on the cross. The foolishness of the cross is a gift leading to life and it sparks a great light of hope which many institutions and people want to extinguish. Hope is not understood, especially when evil appears to triumph. The foolishness of love can overcome evil. "The message of the cross is folly for those who are on the way to ruin, but for those of us who are on the road to salvation it is the power of God" (1 Cor 1,18). 